\title{
Antimicrobial activity and cytotoxicity of transition metal carboxylates derived from agaric acid
}

\begin{abstract}
Original Paper
Habala L. ${ }^{\boxplus}$,Pašková L. ${ }^{2}$, Bilková A. ${ }^{2}$, Bilka F. ${ }^{2}$, Oboňová B. ${ }^{1}$, Valentová J. ${ }^{1}$

${ }^{1}$ Department of Chemical Theory of Drugs, Faculty

of Pharmacy, Comenius University in Bratislava, Kalinčiakova 8, 83232 Bratislava, Slovakia

${ }^{2}$ Department of Cellular and Molecular Biology of Drugs,

Faculty of Pharmacy, Comenius University in Bratislava,

Kalinčiakova 8, 83232 Bratislava, Slovakia

Received 13 November, 2020, accepted 1 March, 2021

Abstract Carboxylato-type transition metal complexes with agaric acid, a bioactive natural compound derived from citric acid, were prepared, and tested in vitro for their antimicrobial activity and cytotoxicity. The products as well as agaric acid itself are amphiphilic compounds containing a hydrophilic head (citric acid moiety) and a hydrophobic tail (non-polar alkyl chain). The putative composition of the carboxylates was assigned on grounds of elemental analysis, infrared (IR) and high-resolution mass spectra (HR-MS), as well as in analogy with known complexes containing the citrate moiety. The metal carboxylates showed interesting activity in several microbial strains, especially against $S$. aureus (vanadium complex; $\mathrm{MIC}=0.05 \mathrm{mg} / \mathrm{ml}$ ). They were also tested for their cytotoxic activity in hepatocytes, the highest activity having been found in the copper(II) and manganese(II) complexes. Further research based on these preliminary results is needed in order to evaluate the influence of parameters like stability of the metal complexes in solution on the bioactivity of the complexes.
\end{abstract}

Keywords Bioinorganic chemistry-metallodrugs-agaric acid-anticancer-antimicrobial-amphiphilic compounds

\section{INTRODUCTION}

Metallodrugs (metallopharmaceuticals) are pharmacologically active substances containing metal atoms, which are essential for their biological activity. They exhibit a number of bioactivities, such as anticancer (Galanski et al., 2003; Hanif and Hartinger, 2018; Johnson et al., 2021), antimicrobial (Regiel-Futyra et al., 2017; Lemire et al., 2013), antiviral (de Paiva et al., 2020), and enzyme inhibitory activities (Kilpin and Dyson, 2013; Habala et al., 2018; Lu and Zhu, 2014). Metallodrugs offer several advantageous features over purely organic compounds due to specific characteristics of coordination compounds. Their bioactivity is influenced by the type of central atom, its oxidation and coordination number, charge of the complex, coordination geometry, type and number of the ligands, and so forth (Ndagi et al., 2017; Frezza et al., 2010).

Agaric acid (agaricin, a-hexadecylcitric acid, 2-hydroxy-1,2,3nonadecanetricarboxylic acid) is a natural compound related to citric acid, substituted at C-4 with a hexadecyl chain (Figure 1). Occasionally, however, the term agaric (agaricin) has been used to describe concentrated or dry extracts from the corresponding fungi, so the usage may be somewhat confusing. It occurs in various wood-decay fungi species. It was initially isolated from the fungus Fomitopsis officinalis but can be found in various other species as well, such as Polyporus officinalis and Polyporus igniarius (Stamets, 2006). Fomitopsis officinalis (synonyms: Laricifomes officinalis, Agaricum officinale) is known also under the common name agarikon. It occurs in temperate regions of the world, although it has recently become very rare in Europe and in Asia. It was first described in antiquity by the Greek physician Dioscorides. The fungus has been used for centuries in traditional medicine, especially in the treatment of tuberculosis and pneumonia (Stamets, 2006). It is sometimes named fly agaric due to its traditional use as insecticide against flies. The mushroom is considered poisonous, though the effects are not severe. Agaricin has been used in traditional medicine in the form of extracts from Fomitopsis officinalis in varying degrees of purity. It has a pronounced anhidrotic effect and can be 


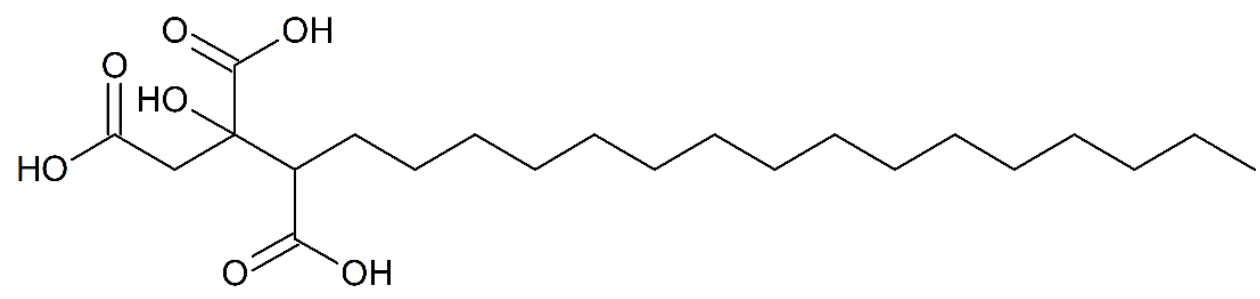

Figure 1. Chemical structure of agaric acid.

used in hyperhidrosis due to its parasympatholytic and anticholinergic activity. It has also been used topically as an anti-inflammatory agent and in the treatment of wounds. Its pharmacological utility was recognized early on, for example, the usefulness of 'white agaric' against excessive perspiration, as reported in 1831 in the journal Lancet (Burdach, 1831). Anticancer activity of agaric acid was mentioned in 1967 (Ciaccio et al., 1967). Despite its interesting pharmacological effects and long-time use in traditional medicine, the available data concerning its bioactivity is limited.

Agaric acid is a highly active inhibitor of fatty acid synthesis in mitochondria, acting by inhibition of the enzyme aconitase (Carrano and Malone, 1967). The mechanism of action is not fully understood but stems most likely from the analogy with citrate, for example, it inhibits citrate uptake in mitochondria (Chávez et al., 1978). Agaric acid is highly inhibitory against malic and a-glycerophosphate dehydrogenases at $\sim 3.10^{-}$ ${ }^{5} \mathrm{M}$ and it also inhibits the growth of the nonpathogenic trypanosomatid Crithidia fasciculata used as a model for the pathogenic representatives of the Trypanosoma genus (Bacchi et al., 1969). Furthermore, it inhibits ADPstimulated respiration. The compound functions as inducer of mitochondrial permeability transition, causing efflux of $\mathrm{Ca}^{2+}$, collapse of transmembrane potential and mitochondrial swelling, probably by binding to mitochondrial ADP/ATP carrier (adenine nucleotide translocase, ANT) (García et al., 2005). The multiple negative charge of the citric moiety seems to be instrumental in this activity, along with the insertion of the alkyl chain into the hydrophobic phase of the membrane. Agaric acid is an amphiphilic-type compound as it contains a hydrophilic head (citric acid moiety) as well as a hydrophobic tail (non-polar alkyl chain). Amphiphilic compounds are a category of substances with specific biological activity. When equipped with suitable donor atoms, they can also act as ligands in metal complexes (Schattschneider et al., 2019). The hydrophobic moiety in the resulting complexes can interact with hydrophobic domains of DNA and proteins as well as with lipid membranes, whereas the central metal ion possesses Lewis acid character and thus can form coordination bonds with suitable donor atoms. Furthermore, it imparts redox properties on such complexes. Aggregation and selfassembly of metallosurfactants leads to metallomicelles.

At physiological $\mathrm{pH}$, all three carboxylic groups of agaric acid can dissociate and are available for complexation, along with the hydroxyl group. However, almost no such metal complexes have been reported so far, except for the platinum complex of agaric acid and 1,2-cyclohexanediammine, whose preparation and anticancer activity in animal model was described (Bitha et al., 1986).

Agaric acid (denoted in this study as ligand L or as compound 8) is a biologically active compound whose pharmacological potential remains largely unexplored. The aim of the presented study was to investigate the influence of complexation with various transition metals on the bioactivity of agaric acid. To this end, transition metal carboxylates of agaric acid with $\mathrm{Cu}$, $\mathrm{Ni}, \mathrm{V}, \mathrm{Co}, \mathrm{La}, \mathrm{Fe}$, and $\mathrm{Mn}$ were prepared. Here, we present the results of the in vitro measurements of their antimicrobial activities and of cytotoxicity in hepatocytes.

\section{MATERIALS AND METHODS}

\section{General}

The chemicals used in the syntheses were purchased from Sigma-Aldrich and are of analytical grade. They were used without further purification. Double distilled water was employed as reaction medium. Infrared (IR) spectra were measured with the help of the ATR (attenuated total reflectance) technique on a Nicolet 6700 FT-IR spectrometer from Thermo Scientific (Waltham, MA, USA) in the 600$4000 \mathrm{~cm}^{-1}$ range. Elemental analysis was conducted using a Flash2000 instrument from Thermo Scientific (Waltham, MA, USA). High-resolution mass spectra (HR-MS) were recorded on Thermo Scientific ${ }^{\text {TM }}$ LTQ Orbitrap XLTM Hybrid Ion Trap-Orbitrap Mass Spectrometer (Thermo Scientific, Waltham, MA, USA). The instrument was used in full-scan mode ( $m / z$ range $100-700)$. The samples were dissolved in HPLC-grade methanol (conc. 2 ppm) and injected directly into the mass spectrometer. Electrospray (ESI) ion source was used to produce the ions. The conductivity measurements of solutions of the metal carboxylates were carried out in 1 $\mathrm{mM}$ dimethyl sulfoxide (DMSO) solutions by means of the conductivity benchtop meter inoLab Cond 7110 (Xylem Analytics, Weilheim, Germany).

\section{General procedure for the synthesis of metal carboxylates}

The metal complexes were prepared according to the modified procedures from (Abrahamson et al., 1994; Deng and 
Zhou, 2009). Agaric acid (0.417 g, $1.0 \mathrm{mmol})$ was suspended in $70 \mathrm{ml}$ of water. The mixture was stirred and heated almost to boiling temperature. Subsequently, a solution of $\mathrm{NaOH}$ (2.0 or $3.0 \mathrm{mmol}$, depending on the charge of the metal cation) in $30 \mathrm{ml}$ of water was added. The heating was continued until complete dissolution of the solid. To the resulting clear colourless solution was added dropwise the aqueous solution of the respective metal salt $(1 \mathrm{mmol})$. The following metal salts (as hydrates) were used: $\mathrm{CuCl}_{2} \cdot 2 \mathrm{H}_{2} \mathrm{O}, \mathrm{MnCl}_{2} \cdot 2 \mathrm{H}_{2} \mathrm{O}, \mathrm{NiCl}_{2} \cdot 6 \mathrm{H}_{2} \mathrm{O}$, $\mathrm{CoCl}_{2} \cdot 6 \mathrm{H}_{2} \mathrm{O}, \mathrm{FeCl}_{3} \cdot 6 \mathrm{H}_{2} \mathrm{O}, \mathrm{La}\left(\mathrm{NO}_{3}\right)_{3} \cdot 6 \mathrm{H}_{2} \mathrm{O}, \mathrm{VOSO}_{4} \cdot 5 \mathrm{H}_{2} \mathrm{O}$. After a short time, coloured precipitate started to form. The reaction mixture was stirred for 3 hours at room temperature. The resulting solid product was separated by filtration, washed successively with water and methanol, and dried in vacuum for several days to yield the product as variously coloured powders.

\section{Antimicrobial activity testing}

Antimicrobial activities of metal complexes and of the ligand were evaluated in vitro and expressed as the minimum inhibitory concentration (MIC). The standard broth dilution method (Lukáč et al., 2010) was employed in the determination. The following strains of Gram-positive, Gramnegative bacteria and a yeast pathogen were selected for the investigation: Staphylococcus aureus CNCTC Mau 29/58, Escherichia coli CNCTC 377/79 and Candida albicans CCM 8186, respectively. All the bacterial strains were obtained from Czech National Collection of Type Cultures (Prague, Czech Republic); yeast was purchased from Czech Collection of Microorganisms (Brno, Czech Republic).

\section{Evaluation of cytotoxicity in HepG2 cells}

HepG2 cells (ATCC HB-8065) were routinely cultured in a humidified atmosphere of $5 \% \mathrm{CO}_{2}$ at $37^{\circ} \mathrm{C}$ in Dulbecco's Modified Eagle Medium (DMEM) containing 10\% Fetal Bovine Serum (FBS) and $0.2 \%(v / v)$ of penicillin/streptomycin solution. Complete medium was replaced every 2 to 3 days. The cultivation was carried out in $100 \mathrm{~mm}$ dishes. The cell count for a passage was 10 to 25 . Cells were trypsinized to detach, then centrifuged, resuspended, seeded at $70 \%$ confluency and grown in 24-well culture plates for $24 \mathrm{~h}$. Afterwards, the cells were incubated with rising inhibitor concentrations $(0-75 \mu \mathrm{g} / \mathrm{ml})$ for $24 \mathrm{~h}$. Inhibitors were dissolved in DMSO. The concentration of vehiculum did not exceed $0.75 \%(\mathrm{v} / \mathrm{v})$ (Miret et al., 2006). At the end of the incubation period, the cell proliferation was appraised using Janus Green B assay as described by Raspotnig et al. (Raspotnig et al., 1999). Briefly, the culture medium was detached from the cell layers by vacuum aspiration and the cell layers were fixed for $30 \mathrm{~min}$ in ethanol (50\%), with subsequent vacuum aspiration of the fixative. Finally, the fixed cell layers were stained for 3 min with a $0.2 \%$ solution of Janus green B in PhosphateBuffered Saline (PBS) (pH 7.1-7.2) at room temperature. After immediate removal of the stain using a vacuum aspirator, the whole plate was washed twice in cold tap water and eluted from cell layers by the addition of a $0.5 \mathrm{ml}$ of $0.5 \mathrm{M} \mathrm{HCl}$. The plate was analysed with a microplate reader (Biotec 3550UV) against blanks of $0.5 \mathrm{M} \mathrm{HCl}$ at $595 \mathrm{~nm}$. The cell count was determined using the calibration curve, which represents the dependency of A595 on HepG2 cell density. Each experiment was conducted threefold in duplicates.

\section{RESULTS AND DISCUSSION}

\section{Synthesis and characterization of the metal complexes}

All the metal carboxylates were prepared in good yields. The synthesis was accomplished in aqueous solution from the sodium salt of agaric acid prepared in situ and corresponding metal salts. The products were powders of various colours, stable in air. The solubility of the resulting metal carboxylates in common solvents was low in all cases. They were moderately soluble in DMSO and DMF (dimethyl formamide), and to some extent, also in alcohols, especially at elevated temperature. The complexes did not melt within the temperature range used. The syntheses are summarized in Table 1, along with the compositions of the metal carboxylates as obtained by elemental analysis and molar conductivities of their DMSO solutions.

The values of electric conductivity in the DMSO solutions (Table 1) suggest their non-ionic nature (Ali et al., 2013). The results of elemental analysis support the metal/ligand ratio 1:1, with varying number of water molecules present in the solid phase ( 2 or 3 ). The metal complexes were further investigated by infrared spectroscopy and high-resolution mass spectroscopy. The selected results of both types of spectroscopic measurements can be found in Table 2 .

In the infrared spectra, bands corresponding to the vibrations of carboxyl groups $(\mathrm{C}=\mathrm{O})$ can be seen at 1539-1590 $\mathrm{cm}^{-1}$ (asymmetric stretching vibration) and 1394-1440 $\mathrm{cm}^{-1}$ (symmetric vibration). In the spectrum of pure agaric acid (the ligand), the band of the protonated carboxyl group appears at $1691 \mathrm{~cm}^{-1}$. The relatively small difference $v_{a s}-v_{s}$ (around 100-200 $\mathrm{cm}^{-1}$ ) indicates the presence of coordinated carboxylate groups bonded to the metal in a covalent, bidentate fashion. The generally much higher intensity of the $v_{\text {as }}\left(\mathrm{COO}^{-}\right)$compared to the symmetric vibration band is a sign of coordinative (non-ionic) nature of the carboxylates (Palacios et al., 2004). The very low value of $\Delta v\left(\mathrm{COO}^{-}\right)$for iron(III) caboxylate $\left(99 \mathrm{~cm}^{-1}\right)$ may be indicative for chelating bridging type of coordination in this complex. In the spectra of the carboxylates with bivalent metals, a residual carboxyl group (apparently protonated) can be seen at 1703-1705 $\mathrm{cm}^{-1}$, whereas in the case of the trivalent metals ( $\left.\mathrm{Fe}, \mathrm{La}\right)$ it is absent. The broad band around $3300 \mathrm{~cm}^{-1}$ can be ascribed to the stretching vibrations of the hydroxyl group of the citrate moiety and the water molecules. The intense signal caused 
Table 1. The prepared metal carboxylates.

\begin{tabular}{|c|c|c|c|c|c|c|c|c|c|}
\hline $\begin{array}{c}\text { Comp. } \\
\text { Nr. }\end{array}$ & $\begin{array}{c}\text { Starting } \\
\text { metal salt }\end{array}$ & Yield & Colour & $\begin{array}{c}\text { Molar } \\
\text { conductivity }\end{array}$ & \multicolumn{2}{c|}{$\begin{array}{c}\text { Assumed } \\
\text { composition }\end{array}$} & \multicolumn{2}{c|}{$\begin{array}{c}\text { Elemental } \\
\text { analysis theor. }\end{array}$} & \multicolumn{2}{c|}{$\begin{array}{c}\text { Elemental } \\
\text { analysis exp. }\end{array}$} \\
\hline & & $\%$ & & $\boldsymbol{\mu S . m o l - 1 . c m 2}$ & & \% C & $\%$ H & $\%$ C & $\% \mathbf{H}$ \\
\hline $\mathbf{1}$ & $\mathrm{CoCl}_{2} \cdot 6 \mathrm{H}_{2} \mathrm{O}$ & 96 & pink & 9 & $\mathrm{Co}(\mathrm{L}-2 \mathrm{H})\left(2 \mathrm{H}_{2} \mathrm{O}\right)$ & 51.84 & 8.31 & 51.70 & 8.55 \\
\hline $\mathbf{2}$ & $\mathrm{CuCl}_{2} \cdot 2 \mathrm{H}_{2} \mathrm{O}$ & 75 & light blue & 3 & $\mathrm{Cu}(\mathrm{L}-2 \mathrm{H})\left(2 \mathrm{H}_{2} \mathrm{O}\right)$ & 51.44 & 8.25 & 51.17 & 8.03 \\
\hline $\mathbf{3}$ & $\mathrm{NiCl}_{2} \cdot 6 \mathrm{H}_{2} \mathrm{O}$ & 82 & light-green & 10 & $\mathrm{Ni}(\mathrm{L}-2 \mathrm{H})\left(3 \mathrm{H}_{2} \mathrm{O}\right)$ & 50.17 & 8.43 & 50.19 & 8.46 \\
\hline $\mathbf{4}$ & $\mathrm{La}\left(\mathrm{NO}_{3}\right)_{3} \cdot 6 \mathrm{H}_{2} \mathrm{O}$ & 87 & white & 2 & $\mathrm{La}(\mathrm{L}-3 \mathrm{H})\left(2 \mathrm{H}_{2} \mathrm{O}\right)$ & 44.90 & 7.02 & 44.91 & 7.19 \\
\hline $\mathbf{5}$ & $\mathrm{VOSO}_{4} \cdot 5 \mathrm{H}_{2} \mathrm{O}$ & 84 & grey-blue & 11 & $\mathrm{VO}(\mathrm{L}-2 \mathrm{H})\left(3 \mathrm{H}_{2} \mathrm{O}\right)$ & 49.34 & 8.28 & 49.30 & 8.03 \\
\hline $\mathbf{6}$ & $\mathrm{FeCl}_{3} \cdot 6 \mathrm{H}_{2} \mathrm{O}$ & 86 & light-brown & 3 & $\mathrm{Fe}(\mathrm{L}-3 \mathrm{H})\left(3 \mathrm{H}_{2} \mathrm{O}\right)$ & 50.46 & 8.28 & 50.50 & 7.95 \\
\hline $\mathbf{7}$ & $\mathrm{MnCl}_{2} \cdot 2 \mathrm{H}_{2} \mathrm{O}$ & 95 & $\begin{array}{c}\text { brownish- } \\
\text { white }\end{array}$ & 5 & $\mathrm{Mn}(\mathrm{L}-2 \mathrm{H})\left(2 \mathrm{H}_{2} \mathrm{O}\right)$ & 52.27 & 8.37 & 52.79 & 8.30 \\
\hline
\end{tabular}

Table 2. Characteristic signals in IR and HR-MS spectra.

\begin{tabular}{|c|c|c|c|c|c|c|}
\hline Substance & $v_{a s}\left(\mathrm{COO}^{-}\right)^{\mathrm{a}}$ & $v_{s}\left(\mathrm{COO}^{-}\right)^{\mathrm{b}}$ & $\Delta v\left(\mathrm{COO}^{-}\right)^{\mathrm{c}}$ & $v(C=0)$ & $m / z$ theor. ${ }^{d}$ & $m / z$ found \\
\hline $1(\mathrm{Co})$ & 1590 & 1394 & 196 & 1704 & 472.1872 & 472.1875 \\
\hline $2(\mathrm{Cu})$ & 1567 & 1417 & 150 & 1704 & 476.1836 & 476.1839 \\
\hline $3(\mathrm{Ni})$ & 1575 & 1417 & 158 & 1704 & 471.1893 & 471.1899 \\
\hline $4(\mathrm{La})$ & 1558 & 1403 & 155 & --- & $(552.1603)$ & --- \\
\hline $5(\mathrm{~V})$ & 1563 & 1423 & 140 & 1705 & 480.1928 & 480.1932 \\
\hline $6(\mathrm{Fe})$ & 1539 & 1440 & 99 & -- & 468.1811 & 468.1816 \\
\hline 7 (Mn) & 1569 & 1409 & 160 & 1703 & (468.1920) & --- \\
\hline $8(L)$ & --- & --- & --- & 1691 & 415.2696 & 415.2701 \\
\hline
\end{tabular}

${ }^{a} v_{c}\left(\mathrm{COO}^{-}\right)$: asymmetric stretching vibration of the carboxyl; ${ }^{b} v_{s}\left(\mathrm{COO}^{-}\right)$: symmetric stretching vibration of the carboxyl; ${ }^{c} \Delta v\left(\mathrm{COO}^{-}\right)=$ $v_{a s}{ }^{a s}\left(\mathrm{COO}^{-}\right)-v_{s}\left(\mathrm{COO}^{-}\right) ;{ }^{d}$ the composition assigned to pseudomolecular ion was in all cases $[\mathrm{M}(\mathrm{L}-\mathrm{nH})]^{-}$, where $n=3-4$, depending on the charge of the metal cation

by asymmetric vibrations of the $\mathrm{COO}^{-}$groups overlaps with coordinated water deformation mode expected at approx. $1640 \mathrm{~cm}^{-1}$. Strong and sharp absorption bands corresponding to $v\left(\mathrm{CH}, \mathrm{CH}_{2}\right)$ vibrations are found at approximately 2850 and $2900 \mathrm{~cm}^{-1}$, those of $\delta\left(\mathrm{CH}, \mathrm{CH}_{2}\right)$ around $1230-1300 \mathrm{~cm}^{-1}$. In the spectrum of the vanadium carboxylate, bands attributed to the vibrations of the $\mathrm{V}=\mathrm{O}$ group can be seen as well: $v_{s}(\mathrm{~V}=\mathrm{O})$ $=988 \mathrm{~cm}^{-1}, v_{a s}(\mathrm{~V}=\mathrm{O})=859 \mathrm{~cm}^{-1}$. Generally, many signals in the spectra of metal carboxylates are shifted towards lower frequencies compared to those of free agaric acid, pointing to changes in vibrational status upon complexation to the respective metal.

The high-resolution mass spectrometry (HR-MS) with ESI ion source provides precise $m / z$ values, enabling in this way the assignment of pseudomolecular ions for the compounds. The attempted ionization in positive mode did not produce molecular ions of the compounds, therefore, we had to resort to mass-spectrometric (MS) measurements in the negative mode. In most cases, we were able to find the pseudomolecular ion with the composition $[\mathrm{M}(\mathrm{L}-3 \mathrm{H})]^{-}$or $[\mathrm{M}(\mathrm{L}-4 \mathrm{H})]^{-}$, except for the carboxylates of lanthanum and manganese. This can be attributed to the instability of these metal complexes in the mass spectrometer. The results support the metal/ligand ratio $1: 1$.

As an example, the HR-MS spectrum of the carboxylate of vanadyl is given in Figure 2. The signal of the pseudomolecular ion of the vanadium complex can be seen at $m / z 480.1932$. The free ligand (anion of agaric acid), originating from the dissociation of the complex, appears at $m / z$ 415.2699.

Regarding the structures of analogous metal complexes with citric acid, it can be concluded that the structures of the prepared complexes might in some cases be dimeric or oligomeric, the great majority of them conforming to 1:1 metal/ligand ratio, for example, Zabiszak et al. (2018), Boghaei and Najafpour (2007), Huta et al. (2012), Field et al. (1974) and Zhou et al. (1999). The exact composition of these citrate complexes is often dependent on the $\mathrm{pH}$ of the reaction solution, for example, in the cobalt(II) complexes with citrate reported in Zhou et al. (2005). The coordination environment of cobalt in these complexes is 


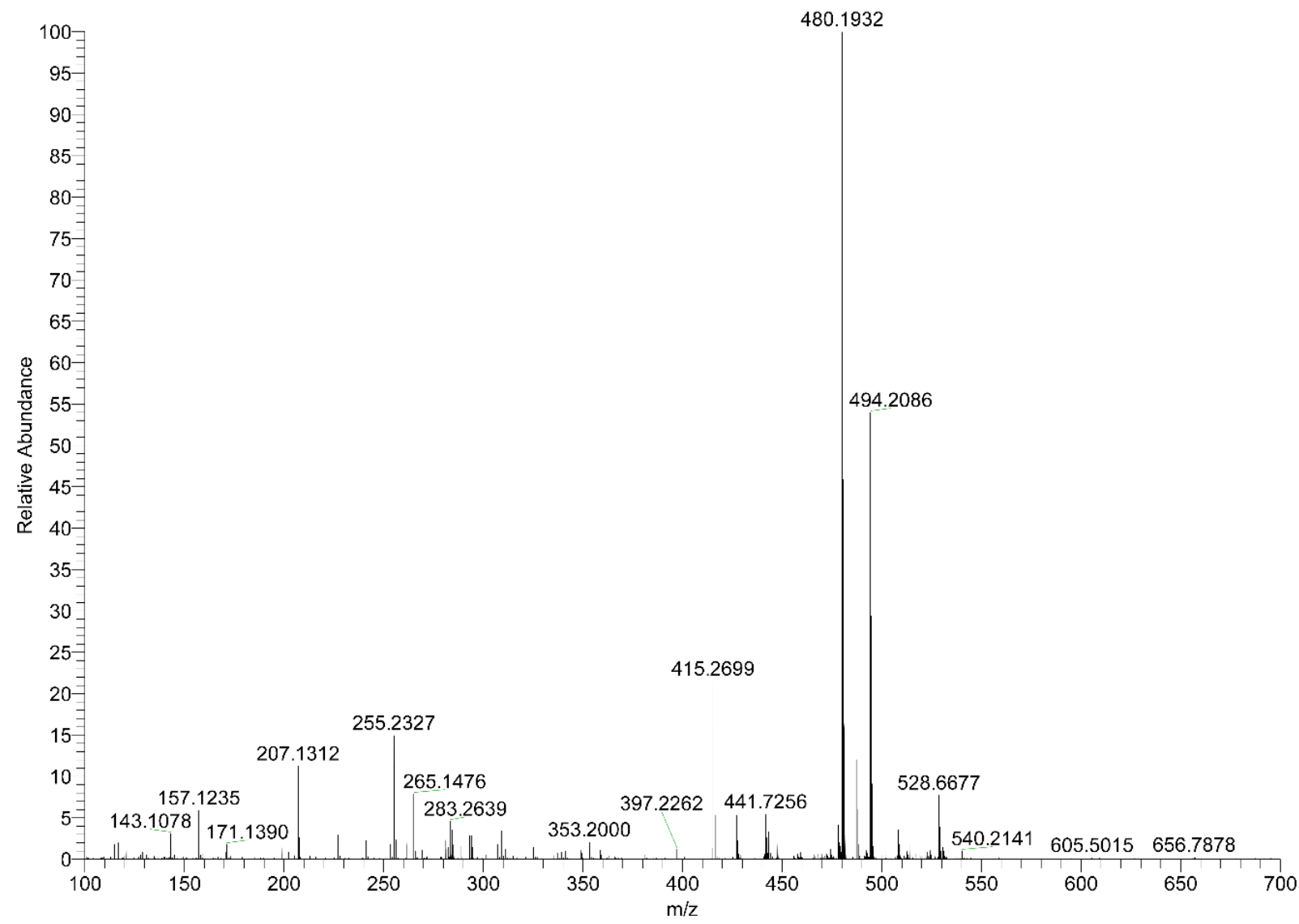

Figure 2. HR-MS spectrum of the vanadium carboxylate (5).

octahedral and the ligand is tridentate, binding through two carboxylates and the hydroxyl group. This type of coordination seems to be prevalent also in complexes with several other metals. With the copper(II) complex, a variety of structures seem possible as well (Boghaei and Najafpour, 2007; Drzewiecka et al., 2007; Mastropaolo et al., 1976). The presence of one or several charge-compensating counter-ions (like $\mathrm{Na}^{+}$) is also possible, as in nickel(II) citrate (Baker et al., 1983) or in iron(III) citrate (Pierre and GautierLuneau, 2000; Vukosav et al., 2012). The ionic nature of any of the corresponding complexes with agaric acid can be fairly ruled out on the grounds of the results of electrical conductivity measurement (low values). The lanthanum complex with citric acid (Baggio and Perec, 2004) exhibits the composition $\left[\mathrm{La}(\mathrm{Hcit})\left(\mathrm{H}_{2} \mathrm{O}\right)\right]_{n}$ and a polymeric structure, which could also fit well with the structure of the agaric acid analog, considering the $\left(v_{a s}-v_{s}\right)$ value for the carboxylate in the IR spectra of the complex. Even if the analogy between complexes of citric and agaric acids might be useful, there are limits to this approach due to the steric requirements of the bulky alkyl substituent in agaric acid. To definitely establish the constitution and geometric arrangement of the metal carboxylates, further research is needed. The most straightforward method, X-ray single-crystal analysis, was not feasible as yet, due to difficulties with the preparation of single crystals of the complexes.

To sum up, the molar ratio metal/ligand 1:1 can be attributed to the prepared complexes. They are of non-ionic nature, most likely with hexacoordinate central atoms surrounded by the partly deprotonated agaric acid and several aqua ligands. They conform to the relative composition $\mathrm{M}(\mathrm{L}-m \mathrm{H})\left(\mathrm{H}_{2} \mathrm{O}\right)_{n}$ where $m, n=2$ or 3 .

\section{Bioactivity}

The prepared complexes along with the ligand were tested for their antimicrobial activity. Two bacterial strains (S. aureus and E. coli) and a yeast strain (C. albicans) were used. The results are summarized in Table 3 . The best results were achieved with the vanadium carboxylate $\mathbf{5}$ in $S$. aureus $(0.05 \mathrm{mg} / \mathrm{ml})$. Interestingly, the activities of the same vanadium complex in C. albicans and E. coli were low. The results in other microbial strains were only inferior. Also, the antimicrobial activity of the copper complex, where the highest effect could be expected, was only mediocre. The activity of the ligand was in the same range as activity of the least active carboxylates. 


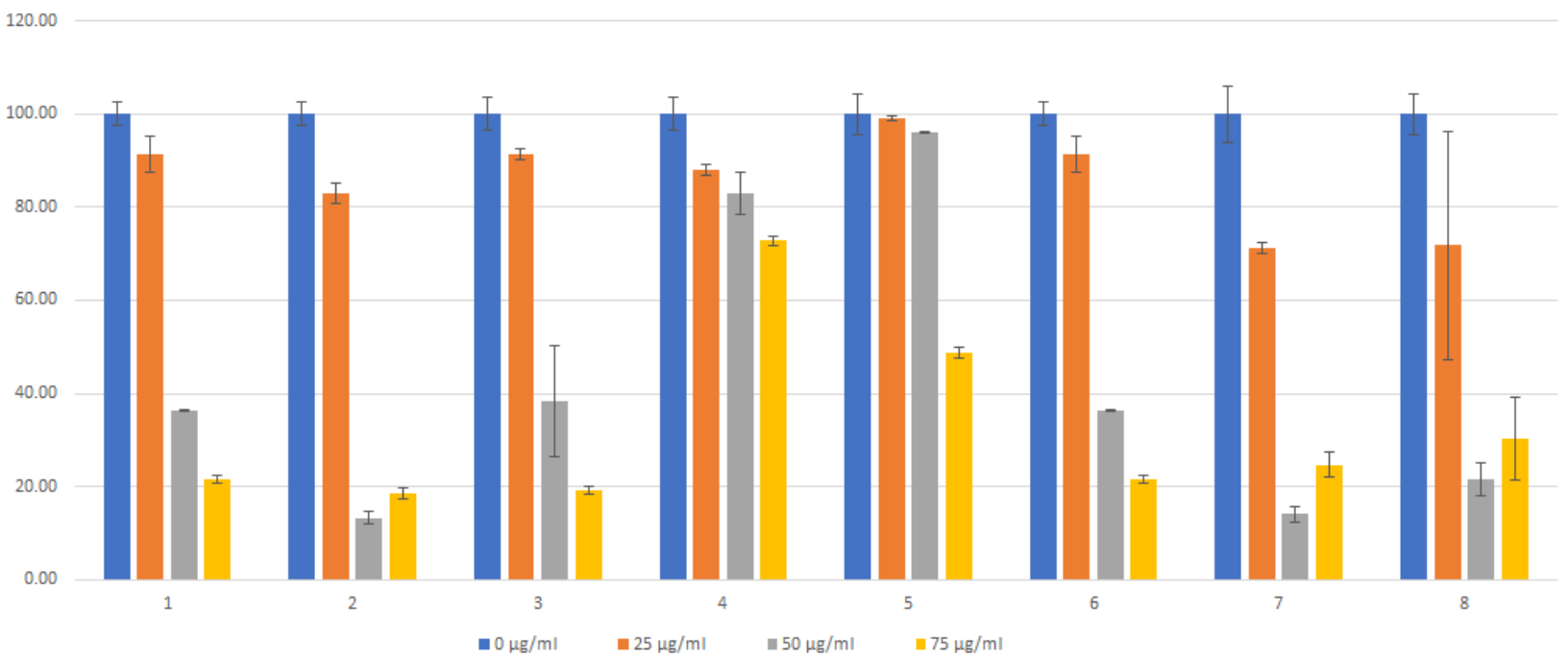

Figure 3. Cell viability for the investigated substances in the concentration range $0-75 \mu \mathrm{g} / \mathrm{ml}$.

Table 3. Antimicrobial activity of metal carboxylates and the ligand (MIC = minimum inhibitory concentration).

\begin{tabular}{|c|c|c|c|c|}
\hline \multirow{2}{*}{$\begin{array}{c}\text { Substance } \\
\text { Nr. }\end{array}$} & \multirow{2}{*}{ Metal } & \multicolumn{3}{|c|}{ MIC (mg/ml) } \\
\cline { 3 - 5 } & & $\begin{array}{c}\text { S. } \\
\text { aureus }\end{array}$ & E. coli & $\begin{array}{c}\text { C. } \\
\text { albicans }\end{array}$ \\
\hline $\mathbf{1}$ & $\mathrm{Co}$ & 0.22 & 0.44 & 0.88 \\
\hline $\mathbf{2}$ & $\mathrm{Cu}$ & 0.44 & 1.75 & 0.44 \\
\hline $\mathbf{3}$ & $\mathrm{Ni}$ & $>3.5$ & 1.75 & 0.88 \\
\hline $\mathbf{4}$ & $\mathrm{La}$ & 1.75 & 1.75 & 1.75 \\
\hline $\mathbf{5}$ & $\mathrm{V}$ & 0.05 & 3.5 & 0.88 \\
\hline $\mathbf{6}$ & $\mathrm{Fe}$ & 3.5 & 0.88 & 0.44 \\
\hline $\mathbf{7}$ & $\mathrm{Mn}$ & 3.5 & 3.5 & 0.44 \\
\hline $\mathbf{8}$ & (ligand) & 1.75 & 3.5 & 0.88 \\
\hline
\end{tabular}

The activities of the free metal ions can be appraised from the literature (Harrison et al., 2004; Nies, 1999)

To estimate the anticancer properties of the considered compounds, cytotoxicity in the human liver cancer cell line HepG2 was evaluated. HepG2 is an immortal cell line derived from hepatocellular carcinoma. It represents an in vitro model system for investigation of polarized human hepatocytes. The cell viability (percentage of cell survival) was determined in the concentration range $0-75 \mu \mathrm{g} / \mathrm{ml}(25 \mu \mathrm{g} / \mathrm{ml}$ step). The results are shown in Figure 3.

All the investigated complexes appear to be cytotoxic at the studied concentrations. The ligand itself (8) also exhibited comparatively high activity $(21.5 \%$ at $50 \mu \mathrm{g} / \mathrm{ml})$. The activities of the free metal ions can be appraised from the literature (Borenfreund and Puerner, 1986).

The highest cytotoxicity was exercised at $50 \mu \mathrm{g} / \mathrm{ml}$ by the copper complex $\mathbf{2}$ and the manganese complex 7 (13.3 and $14.1 \mu \mathrm{g} / \mathrm{ml}$, respectively). Interestingly, at $50 \mu \mathrm{g} / \mathrm{ml}$ the activities of all the complexes except these two were lower than the activity of the ligand but the picture changes at 75 $\mu \mathrm{g} / \mathrm{ml}$, where all the complexes except those of La and V score better than the pure ligand. Thus, the formation of metal carboxylates seems to improve upon the activity of the ligand (agaric acid), except in the case of the vanadium complex and even more so in the case of the lanthanum carboxylate. It is difficult to give a proper explanation for this synergic effect but binding of agaric acid to the metal might possibly facilitate the crossing of the cell membrane and thus accumulation of the metal in the cell. Similar improvement of cell membrane passage was observed in the amphiphilic Ru(II) complex reported in Siewert et al. (2017). Charged ruthenium species generally exhibit low cellular uptake (Alessio, 2016), yet this was radically improved upon incorporation of a $C_{12}$ alkyl chain into the aforementioned ruthenium complex. Synergic effect of $\mathrm{Cu}(\mathrm{II}) / \mathrm{Fe}$ (III) complexation of non-ionic amphiphilic Schiff bases on antimicrobial activities was shown by Negm and Zaki (2008). It can be concluded that the donor atoms represent a highly hydrophilic area within the ligand, thus the lipophilicity of the complex molecule increases upon coordination to metal ions (decreasing the electron density of the moiety). This might lead to increased adsorption on the lipid-containing cell walls and affect the permeability of the membranes, resulting in more facile passage through the cell membrane of the microbes (Negm and Zaki, 2008; Schattschneider et al., 2019).

Another effect exercised by amphiphilic complexes could be improved protein binding, as demonstrated in the cobalt(III) complex carrying two phenanthroline ligands and a hydrophobic tetradecylamine ligand with a high affinity to human serum albumin (HSA) (Kumar et al., 2011). An amphiphilic complex of cobalt(III) carrying a dodecylamine ligand is able to intercalate with its long hydrophobic 
chain between the base pairs in DNA, as indicated by cyclic voltammetry, spectroscopic methods and DNA viscosity measurements (Nagaraj and Arunachalam, 2014).

\section{CONCLUSIONS}

Agaric acid is a natural compound with manifold biological activities. In the course of this work, 7 new compounds, that is, carboxylates of agaric acid with transition metals were prepared. The complexes and the ligand (agaric acid) were tested for their in vitro antimicrobial activity against bacteria and yeast, as well as for their cytotoxicity in the hepatocytic cancer cell line HepG2.

Considerable antibacterial activity was found in the vanadium carboxylate, active against $S$. aureus. The majority of the complexes showed marked anticancer in vitro activity. The cytotoxicity was highest for the copper and manganese carboxylates.

The results are generally encouraging, especially considering that the expected molecular mass of the carboxylates might be quite high, and the complexes thus exhibit activity at low molar concentrations. The compounds are also interesting because of their amphiphilic nature. Hence, further investigation of these carboxylate complexes would be worthwhile, in particular into their structure and additional bioactivities. Of special interest is the evaluation of the behaviour of the complexes in solution, since they may undergo various changes upon dissolution, such as ligand dissociation and exchange. Based on the available analytical data, the complexes might be oligomeric or polymeric, thus their structure in aqueous solution can differ considerably from the solid-state structure.

\section{ACKNOWLEDGMENTS}

This publication was supported by the Scientific Grant Agency of the Slovak Republic, grant VEGA 1/0145/20, and Comenius University grant UK/324/2020.

\section{CONFLICT OF INTEREST}

The authors declare that they have no conflict of interest.

\section{References}

[1] Abrahamson HB, Rezvani AB, Brushmiller JG. Photochemical and spectroscopic studies of complexes of iron(II1) with citric acid and other carboxylic acids. Inorg Chim Acta. 1994;226:117-127.

[2] Alessio E. Thirty years of the drug candidate NAMI-A and the myths in the field of ruthenium anticancer compounds: a personal perspective. Eur J Inorg Chem. 2017;2017:1549-1560.

[3] Ali I, Wani WA, Saleem K. Empirical formulae to molecular structures of metal complexes by molar conductance. Synth React Inorg Met-Org Chem. 2013;43:1162-1170.

[4] Bacchi CJ, Ciaccio El, Koren LE. Effects of some antitumor agents on growth and glycolytic enzymes of the flagellate Crithidia. $J$ Bacteriol. 1969;98:23-28.

[5] Baggio R, Perec M. Isolation and characterization of a polymeric lanthanum citrate. Inorg Chem. 2004;43:6965-6968.

[6] Baker EN, Baker HM, Anderson BF, Reeves RD. Chelation of nickel(II) by citrate. The crystal structure of a nickel-citrate complex, $\mathrm{K}_{2}\left[\mathrm{Ni}\left(\mathrm{C}_{6} \mathrm{H}_{5} \mathrm{O}_{7}\right)\left(\mathrm{H}_{2} \mathrm{O}\right)_{2}\right]_{2}$. Inorg Chim Acta. 1983;78:281-285.

[7] Bitha P, Child RG, Hlavka JJ, Lin Y. Platinum complexes of aliphatic tricarboxylic acid. EP0185225A1, Jun 25, 1986

[8] Boghaei DM, Najafpour MM. Crystal structure of $\mathrm{Gua}_{4}\left[\mathrm{Cu}_{2}(\mathrm{Cit})_{2}\right] \quad\{\mathrm{Gua}=$ Guanidinium, Cit $=$ Citrate $=2$-hydroxo1,2,3-tricarboxylatopropane\}. Anal Sci. 2007;23:23-24.

[9] Borenfreund E.; Puerner JA. Cytotoxicity of metals, metal-metal and metal-chelator combinations assayed in vitro. Toxicology. 1986;39:121-134.

[10] Burdach M. Use of the white agaric in night perspirations. The Lancet. 1831;16:316.

[11] Carrano RA, Malone MH. Pharmacologic study of norcaperatic and agaricic acids. J Pharm Sci. 1967;56:1611-1614.
[12] Chávez E, Chávez R, Carrasco N. The effect of agaric acid on citrate transport in rat liver mitochondria. Life Sci. 1978;23:1423-1429.

[13] Ciaccio El, Boxer GE, Devlin TM, Ford RT. Screening data from selected in vitro enzymatic systems I. Standard test compounds from the Cancer Chemotherapy Nation Service Center. Cancer Res. 1967;27:1033-1069.

[14] Ciaccio El, Boxer GE, Devlin TM, Ford RT. Screening data from selected in vitro enzymatic systems II. Compounds specifically selected for the dehydrogenase inhibition screens. Cancer Res. 1967;27:1070-1104.

[15] de Paiva REF, Marçal Neto A, Santos IA, Jardim ACG, Corbi PP, Bergamini FRG. What is holding back the development of antiviral metallodrugs? A literature overview and implications for SARS-CoV-2 therapeutics and future viral outbreaks. Dalton Trans. 2020;49:16004-16033.

[16] Deng YF, Zhou ZH. Synthesis and crystal structure of a zinc citrate complex $\left[\mathrm{Zn}\left(\mathrm{H}_{2} \mathrm{Cit}\right)\left(\mathrm{H}_{2} \mathrm{O}\right)\right]_{n}$. J Coord Chem. 2009;62:1484-1491.

[17] Drzewiecka A, Koziol AE, Lowczak M, Lis T. Poly[tetraaquadi$\mu_{6}$-citrato-tetra-copper(II)]: a redetermination. Acta Cryst. 2007;E63:m2339-m2340.

[18] Field TB, McCourt JL, McBryde WAE. Composition and stability of iron and copper citrate complexes in aqueous solution. Can J Chem. 1974;52:3119-3124.

[19] Frezza M, Hindo S, Chen D, Davenport A, Schmitt S, Tomco D, Dou QP. Novel metals and metal complexes as platforms for cancer therapy. Curr Pharm Des. 2010;16:1813-1825.

[20] Galanski M, Arion VB, Jakupec MA, Keppler BK. Recent developments in the field of tumor-inhibiting metal complexes. Curr Pharm Des. 2003;9:2078-2089. 
[21] García N, Zazueta C, Pavón N, Chávez E. Agaric acid induces mitochondrial permeability transition through its interaction with the adenine nucleotide translocase. Its dependence on membrane fluidity. Mitochondrion. 2005;5:272-281.

[22] Habala L, Devínsky F, Egger AE. Metal complexes as urease inhibitors. J Coord Chem. 2018;71:907-940.

[23] Hanif M, Hartinger CG. Anticancer metallodrugs: where is the next cisplatin? Future Med Chem. 2018;10:615-617.

[24] Harrison JJ, Ceri H, Stremick CA, Turner RJ. Biofilm susceptibility to metal toxicity. Environ Microbiol. 2004;6:1220-1227.

[25] Huta B, Lensboeur JJ, Lowe AJ, Zubieta J, Doyle RP. Metal-citrate complex uptake and CitMHS transporters: From coordination chemistry to possible vaccine development. Inorg Chim Acta. 2012;393:125-134.

[26] Johnson A, Northcote-Smith J, Suntharalingam K. Emerging metallopharmaceuticals for the treatment of cancer. Trends Chem. 2021;3:47-58.

[27] Kilpin KJ, Dyson PJ. Enzyme inhibition by metal complexes: concepts, strategies and applications. Chem Sci. 2013;4:14101419.

[28] Kumar RS, Paul P, Riyasdeen A, Wagniéres G, van den Bergh H, Akbarsha MA, Arunachalam S. Colloids Surf B Biointerfaces. 2011;86:35-44.

[29] Lemire JA, Harrison JJ, Turner RJ. Antimicrobial activity of metals: mechanisms, molecular targets and applications. Nat Rev Microbiol. 2013;11:371-384.

[30] Lu L, Zhu M. Protein tyrosine phosphatase inhibition by metals and metal complexes. Antioxid Redox Signal. 2014;20: 22102224.

[31] Lukáč M, Lacko I, Bukovský M, Kyselová Z, Karlovská J, Horváth B, Devínsky F. Synthesis and antimicrobial activity of a series of optically active quaternary ammonium salts derived from phenylalanine. Open Chem. 2010;8:194-201.

[32] Mastropaolo D, Powers DA, Potenza JA, Schugar HJ. Crystal structure and magnetic properties of copper citrate dihydrate, $\mathrm{Cu}_{2} \mathrm{C}_{6} \mathrm{H}_{4} \mathrm{O}_{7} \cdot 2 \mathrm{H}_{2} \mathrm{O}$. Inorg Chem. 1976;15:1444-1449.

[33] Miret S, De Groene EM, Klaffke W. Comparison of in vitro assays of cellular toxicity in the human hepatic cell line HepG2. J Biomol Screen. 2006;11:184-193.

[34] Nagaraj K, Arunachalam S. Synthesis, CMC determination, nucleic acid binding and cytotoxicity of a surfactant-cobalt(iii) complex: Effect of ionic liquid additive. New J Chem. 2014;38:366-375.

[35] Ndagi U, Mhlongo N, Soliman ME. Metal complexes in cancer therapy - an update from drug design perspective. Drug Des Devel Ther. 2017;11:599-616.

[36] Negm NA, Zaki MF. Structural and biological behaviors of some nonionic Schiff-base amphiphiles and their $\mathrm{Cu}(\mathrm{II})$ and $\mathrm{Fe}(\mathrm{III})$ metal complexes. Colloids Surf B Biointerfaces. 2008;64:179-183.

[37] Nies DH. Microbial heavy-metal resistance. Appl Microbiol Biotechnol. 1999;51:730-750.

[38] Palacios EG, Juárez-López G, Monhemius AJ. Infrared spectroscopy of metal carboxylates II. Analysis of Fe(III), Ni and Zn carboxylate solutions. Hydrometallurgy. 2004;72:139-148.
[39] Pierre JL, Gautier-Luneau I. Iron and citric acid: A fuzzy chemistry of ubiquitous biological relevance. BioMetals. 2000;13:91-96.

[40] Raspotnig G, Fauler G, Jantscher A, Windischhofer W, Schachl $\mathrm{K}$, Leis $\mathrm{HJ}$. Colorimetric determination of cell numbers by Janus green staining. Anal Biochem. 1999;275:74-83.

[41] Regiel-Futyra A, Dąbrowski JM, Mazuryk O, Śpiewak K, Kyzioł A, Pucelik B, Brindell M, Stochel G. Bioinorganic antimicrobial strategies in the resistance era. Coord Chem Rev. 2017;351:76117.

[42] Schattschneider C, Kettenmann SD, Hinojosa S, Heinrich J, Kulak N. Biological activity of amphiphilic metal complexes. Coord Chem Rev. 2019;385:191-207.

[43] Siewert B, Langerman M, Hontani Y, Kennis JTM, van Rixel VHS, Limburg B, Siegler MA, Talens Saez V, Kieltyka RE, Bonnet S. Turning on the red phosphorescence of a $[\mathrm{Ru}(\mathrm{tpy})(\mathrm{bpy})(\mathrm{Cl})] \mathrm{Cl}$ complex by amide substitution: self-aggregation, toxicity, and cellular localization of an emissive ruthenium-based amphiphile. Chem Commun. 2017;53:11126-11129.

[44] Stamets P. Antiviral activity from medicinal mushrooms. US 2006/0171958 Al, Aug 3, 2006

[45] Vukosav P,Mlakar M,TomišićV. Revision of iron(III)-citrate speciation in aqueous solution. Voltammetric and spectrophotometric studies. Analyt Chim Acta. 2012;745:85-91.

[46] Zabiszak M, Nowak M, Taras-Goslinska K, Kaczmarek MT, Hnatejko Z, Jastrzab R. Carboxyl groups of citric acid in the process of complex formation with bivalent and trivalent metal ions in biological systems. J Inorg Biochem. 2018;182:37-47.

[47] Zhou ZH, Deng YF, Wan HL. Structural Diversities of Cobalt(II) Coordination Polymers with Citric Acid. Cryst Growth Des. 2005;5:1109-1117.

[48] Zhou ZH, Zhang H, Jiang YQ, Lin DH, Wan HL, Tsai KR. Complexation between vanadium $(\mathrm{V})$ and citrate: spectroscopic and structural characterization of a dinuclear vanadium(V) complex. Trans Met Chem. 1999;24:605-609. 